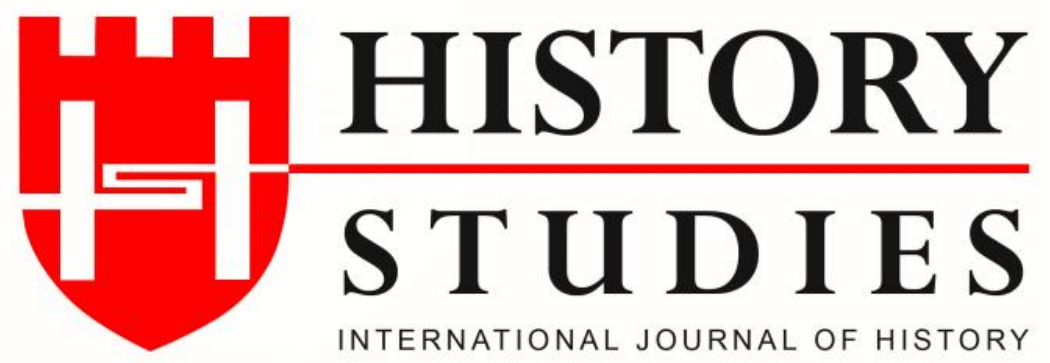

ISSN: 13094173 (Online) 1309 - 4688 (Print)

Volume 11 Issue 6, December 2019

DOI Number: 10.9737/hist.2019.797

Araştırma Makalesi

Makalenin Geliş Tarihi: 21.10.2019 Kabul Tarihi: 13.12.2019

Atıf Künyesi: Burak Eryılmaz, “Unearthing the Past: Passport Regulations in the Ottoman Empire”, History Studies, 11/6, Aralık 2019, s. 2003-2015.

\title{
UNEARTHING THE PAST: PASSPORT REGULATIONS IN THE OTTOMAN EMPIRE
}

Geçmişi Ortaya Çıkartmak: Osmanlı Devleti’nde Pasaport Düzenlemeleri

\author{
Dr. Burak Eryılmaz \\ ORCID No: 0000-0002-2179-5450 \\ Amasya Üniversitesi
}

\begin{abstract}
This paper is to examine the legislations on the entrance to the Ottoman Empire territories, travelling inside the country, and passports. A review of literature has revealed that much has been said by the scholars from the history departments, but little has been said by any researcher from the departments of tourism. This paper is to investigate into the legislations that affected the development of tourism during the reign of Ottoman Empire and to reveal the philosophy of the state on the tourism. The results indicate that the legislations during the Ottoman period concur well with the current ones, and the very first legislations during the Ottoman Period laid the foundations of the current tourism system.
\end{abstract}

Keywords: The Ottoman Empire, Passport, Tourism, Travel

Özet: $\mathrm{Bu}$ araștırmanın amacı Osmanlı İmparatorluğu hâkimiyetindeki topraklara giriș-çıkıș, ülke içinde seyahat etme ve pasaportlar ile ilgili düzenlemeleri incelemektir. Araştırma konusu ile ilgili alan yazın taraması, turizm alanından araştırmacılar tarafından yapılan çalışmaların tarih alanındaki araştırmacılara oranla görece az olduğu sonucunu göstermiştir. Bu bağlamda bu araştırma, Osmanlı İmparatorluğu döneminde meydana gelen turizm gelişmelerini etkileyen yasal düzenlemeler ve devletin turizm yaklaşımını ele almaktadır. Elde edilen sonuçlar turizm alanında Osmanlı İmparatorluğu dönemi düzenlemelerin günümüzdekilerle örtüştüğünü ve Osmanlı Devleti döneminde yapılan bu düzenlemelerin mevcut turizm uygulamalarının temelini oluşturduğunu göstermiştir.

Anahtar Kelimeler: Osmanlı İmparatorluğu, Pasaport, Turizm, Seyahat.

\section{Introduction}

The Ottoman Empire reigned over the junction point of the East and the West cultures. Several significant historical, cultural and religious attractions that still display the traces of the past were inherited to the Ottoman Empire since the Anatolian territories had hosted many different civilizations from the antiquity. Some increases in the number of the individuals who wish to discover this inheritance and visit holy places have been reported since $16^{\text {th }}$ century. ${ }^{1}$ One of the most striking examples of this inheritance can be seen in Macedonia which has deep traces of a wide range of cultures and the remnants can be seen today in different cultural relicts that dispersed across the country. In this sense, there are almost 20 original sites which can be visited by the tourists. ${ }^{2}$ In this sense, western Europeans and Americans were appealed

\footnotetext{
${ }^{1}$ Gerald MacLean, Writing Turkey: Explorations in Turkish history, politics, and cultural identity. London: Middlesex University Press, 2006.

${ }^{2}$ Ivanka Nestoroska, Biljan Petrevska and Peter Namicev, Ottoman heritage tourism flows in Macedonia. YearbookFaculty of Tourism and Business Logistics, 3(2), 2018, p.89-99.
}

\section{History Studies}


by the attractions in the Ottoman territories, and the tourism potential has increased thanks to the new transportation technologies such as steam shipping. Additionally, the travel narratives proliferating after 1830 made the Ottoman territories and culture more attractive to foreigners . ${ }^{3}$ On the other hand, according to Nance $(2007)^{4}$ due to the fact that the Ottoman Empire was home to the diverse communities of Arabs, Turks, and European expatriares, it evolved into one of the most talked about touristic attractions and destinations in $19^{\text {th }}$ century. Toprak $(1993)^{5}$ mentions that foreigners showed great interest to the Ottoman Empire as a result of Sergi-i Umum-i Osmani held in İstanbul in 1863. At times, masses of crowds were visiting the Ottoman territories, particularly İstanbul. An increase in the number of the hotels, restaurants and advertisements on them in newspapers as well as paying attention to the touristic places while planning the city can be considered as the onset of the tourism industry. ${ }^{6}$

Additionally, more people visited the Ottoman territories thanks to the advances in transportation and communication means during the $19^{\text {th }}$ century. On the other hand, what was more important was that most of the visitors published travelogues following their journeys and shared their experiences. Travelogues became guides for scholars, religious people, traders and adventurers along with contributing to the recognition of Ottoman Territories. ${ }^{7}$ When it comes to the tourism activities in Ottoman Empire, it can be noted that some people in diversified communities were earning a living through providing transportation to those who made family visits inside the country, whereas others were hosting those who were having pilgrimage experiences to Mecca, Medina, and Jeruselam from Asia, Africa and Europe. ${ }^{8}$ During the mids of the $19^{\text {th }}$ century, people were visiting the Jeruselam was either by walking or on animal backs. However, since the mid-1850s, the changes that occured in the means of transport paved the way for an increase in the number of tourists arriving to Jerusalem, thereby leading to tourism to grow. Additionally, a road was built after the order of the Sultan of Turkey in 1867, coaches were started to be used on this route. ${ }^{9}$ O'Byrne $(2001)^{10}$ comments on this situation, uttering that the opening up of the world for touristic consumption is a consequence of the developed means of transportation.

As the number of the journeys to the Ottoman territories increased, more accommodation, food and drinks, as well as guidance and translating services were also needed. In this sense, the state introduced some certain legislations related to tourism directly or indirectly that are similar to the current ones in order to achieve safety for both the state itself and welfare of the public. The most prominent applications are as follows: A kind of visa document called as "Mürur Tezkiresi", and passport regulations. Even though it would be too assertive to mention that the legislations and regulations were related to those who wanted to visit the country for

\footnotetext{
3 Kiristin Hoganson, Cosmopolitan domesticity: Importing the American dream, 1865-1920. The American Historical Review, 107(1), 2002, p. 55-83.

${ }^{4}$ Susan Nance, A facilitated access model and Ottoman Empire tourism. Annals of Tourism Research, 34(4), 2007,p.1056-1077.

5 Zafer Toprak, 'Seyyah’tan 'Turist'e 'Sınâat'tan 'Endüstri’ye "Ecânib Sinâatı” (Türkiye'e 'Ecânib Sinâatı' ya da

'Turizm Endüstrisi'). İstanbul: Tarih Vakf1 Yayını, 6, 1993, p.66-69.

${ }^{6}$ Cüneyt Mengü, Sezgi Gedik, Suna Muğan Ertuğral, "The Central Government Efoorts to Promote Tourism in The Ottoman Empire”, Osmanlı Mirası Araştırmaları Dergisi,6/14, 2019, s. 115-127.

${ }^{7}$ Ayşegül Kuş, Henry John Van Lennep ee Göre Amasya. GOSOS/Gaziosmanpaşa Üniversitesi Sosyal Bilimler Araştırmaları Dergisi, 11/1, 2016.

${ }^{8}$ Susan Nance, 2007.

${ }^{9}$ Noam Shoval and Kobi Cohen-Hattab, Urban hotel development patterns in the face of political shifts. Annals of Tourism Research, 28(4), 2001, p. 908-925.

${ }^{10}$ Darren O'Byrne, On passports and border controls. Annals of Tourism Research, 28(2), 2001, p. 399-416.
} 
touristic purposes as it is today, it can be noted that they had to be addressed by those who travelled to the Ottoman territories and institutions no matter what their purposes were.

This article starts by framing the tourism regulations in the Ottoman territories. It then provides some examples of the regulations on the entrance the country. Following this, it introduces the legal requirements on the entrance, stay and exit of the foreigners in the Ottoman territories, and passport regulations. Its contribution ends with the conclusions and implications of the related data on the tourism regulations during the Ottoman Empire Period from the perspective of a researcher studying the department of tourism rather than a historical one. In conclusion, I discuss the recommendations for further research.

\section{Literature Review}

The latter half of the 20th century witnessed the expansion of the tourism industry and the new opportunities for travels. In this sense, today's tourists have a world to choose from. Correspondingly, the expansion of tourism into an enormous economic sector has made some regulations on tourism activities, including entrance and exit from the countries, namely visa applications, accommodations, transportations, translators, and so on. ${ }^{11}$ In this regard, it can be noted that tourism has evolved into an indispensable part of economies throughout the world.

Previous research has revealed that very few scholars have focused on the legislative regulations on tourism during the Ottoman Empire period. Additionally, very little has been written within the social sciences about the passport regulations. This is very strange indeed in that passports can be seen as a means of identification during the border controls and it shouldn't be taken for granted.

The work of Nance (2007) ${ }^{12}$ tells us that travellings to the Ottoman territories for touristic purposes from the West had existed before the tours to the Anatolia operated by the Company of Thomas Cook in 1869. As an explanation for this, the author stated that the tourist attractions in the Ottoman territories must have captured the tourists' interest. In the study conducted by Nestoroska, Petrevska, and Namicev (2018), ${ }^{13}$ it was attempted to investigate the presence of current and potential tourism heritage flow based upon cultural heritage in Macedonia dating from the Ottoman period.

\section{Method}

This study adopted a qualitative research methodology. In this sense, the document analysis research design was employed. Yıldırım and Şimşek $(2008)^{14}$ considers the document analysis method as the examination of the written documents about the research topic in a systematic way. Walliman $(2015)^{15}$ argues that all research studies rest on secondary data for the background of the study. Even some rely greatly on them for the whole study. Historical data, namely the archive content is the primary and the most reliable resource in historical studies. ${ }^{16}$ According to Walliman (2015), the qualitative data mostly come from literary texts, minutes of meetings, observation notes, interview transcripts, documentary films, historical records, memos and recollections, etc. In this sense, the detailed examination of historical documents (Jupp, 2006) has been conducted in this study.

\footnotetext{
${ }^{11}$ Darren O'Byrne, 2001.

${ }^{12}$ Susan Nance, 2007.

${ }^{13}$ Ivanka Nestoroska, Biljan Petrevska and Peter Namicev, 2018.

${ }^{14}$ Ali Yıldırım and Hasan Şimşek, Sosyal Bilimlerde Nitel Araştırma Yöntemleri (6. Baskı), Seçkin Yayıncılık, Ankara, 2008.

${ }^{15}$ Nicholas Walliman, Social research methods: The essentials. London: Sage, 2015.

${ }^{16}$ Victor Jupp, The Sage dictionary of social research methods. London: Sage, 2006.
} 
In a study resting on historical data, it can be an enormous task to rummage through dustry archieves in an obscure library ${ }^{24}$. Therefore, a systematic review of previous research has been conducted in the historical archive of the Ottoman Empire. First of all, the related documents were found and then adapted into the current language. Thanks to the accessilibity to the Ottoman archives in İstanbul by the scientific community, academic attention has shifted from the conventional methods of collecting data, including chronicles, traveler accounts to the official records of the state. ${ }^{17}$ In this sense, there were some steps in collection data in this study: (1) Access to the data, (2) Checking the authenticity, (3) Comprehensibility of the data, (4) Analyzing and (5) Employing the obtained data. In order to get the related data, the official permission was obtained from the Directorate General of State Archives in Turkey. Following the related documents were requested through online system. There is no authenticity problem with the documents in the library as it is an official state institution. According to İlhan (2008), ${ }^{18}$ an elaborate and accurate simplification, transliteration and translation of the Ottoman chronicles and archival documents are essential for good analyses of the historical events. Such a viewpoint will help avoiding misinterpretation. At this precise point, A language and history expert guided the researcher to find the correct data and to figure out the documents of the research topic. After a detailed examination the historical data, the relevant documents were employed in this paper. In this study, it was attempted to fill the void in the literature, by revealing the archive content on tourism law and practices during the Ottoman Period. For this purpose, some information on efforts given to develop and to control the tourism based on the archive content was revealed.

Along with the archive content, the studies on tourism in the Ottoman period were examined. The following research questions framed the study:

What were the laws and legislative regulations on visa and passport practices for those who wished to visit the country, accommodation (hotels and guesthouses), and tourist guiding?

1. What were the motivations for these legislative regulations?

2. How did they practice these regulations?

3. What were the problems that occured due to the practices?

\section{Findings}

\section{Legal requirements on the entrance, stay and exit of foreigners in the Ottoman Territories}

\section{Mürur Tezkiresi (The Trip Permission) and Travellings}

There were several restrictions upon the travelling inside the state during the Ottoman Period. Both local residents and foreigners had to get some official documents called as "yol hükmü (hereafter, the route pass)" in $16^{\text {th }}$ century and "Mürur Tezkiresi (hereafter, the trip permission)" in the $19^{\text {th }}$ century to travel inside the state. The administrators of the settlements in which the visitors would pass were assigned with authorities in the route passes. In this regard, administrators were ordered to help the ambassadors of the foreign states, traders, religious people, to protect them, and not to disturb them with such reasons as collecting taxes, as well as to assist them in getting food and drinks. ${ }^{19}$

\footnotetext{
${ }^{17}$ Heath W. Lowry, Ottoman Bursa in travel accounts. Tarih Incelemeleri Dergisi, 20(1), 2003, p. 211-212.

${ }_{18}$ Mehdi İlhan, An Overview of the Ottoman Archival Documents and Chronicles. Tarih Araştırmalart Dergisi, 27(44),2008, p. 21-40.

${ }^{19}$ Mübahat Kütükoğlu, Mürur Tezkiresi. TDVİA, c. XXXII, Ankara, 2006, p. 60.
} 
In the trip permissions, the information on the name of the father, nationality, address and travelling route of the travellers were included. During the period in which the photos didn't exist or weren't prevalent, some information on the age, height, and physical descriptions (beard, moustache, eye color, etc.) were included in the document. Figure 1 displays a sample of 'the trip permission' given to the individual with the name Salih Şerbetçi Mehmed.

Figure 1: A sample of 'the trip permission' given to Salih Şerbetçi Mehmed

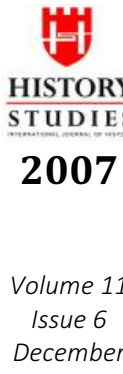

2019
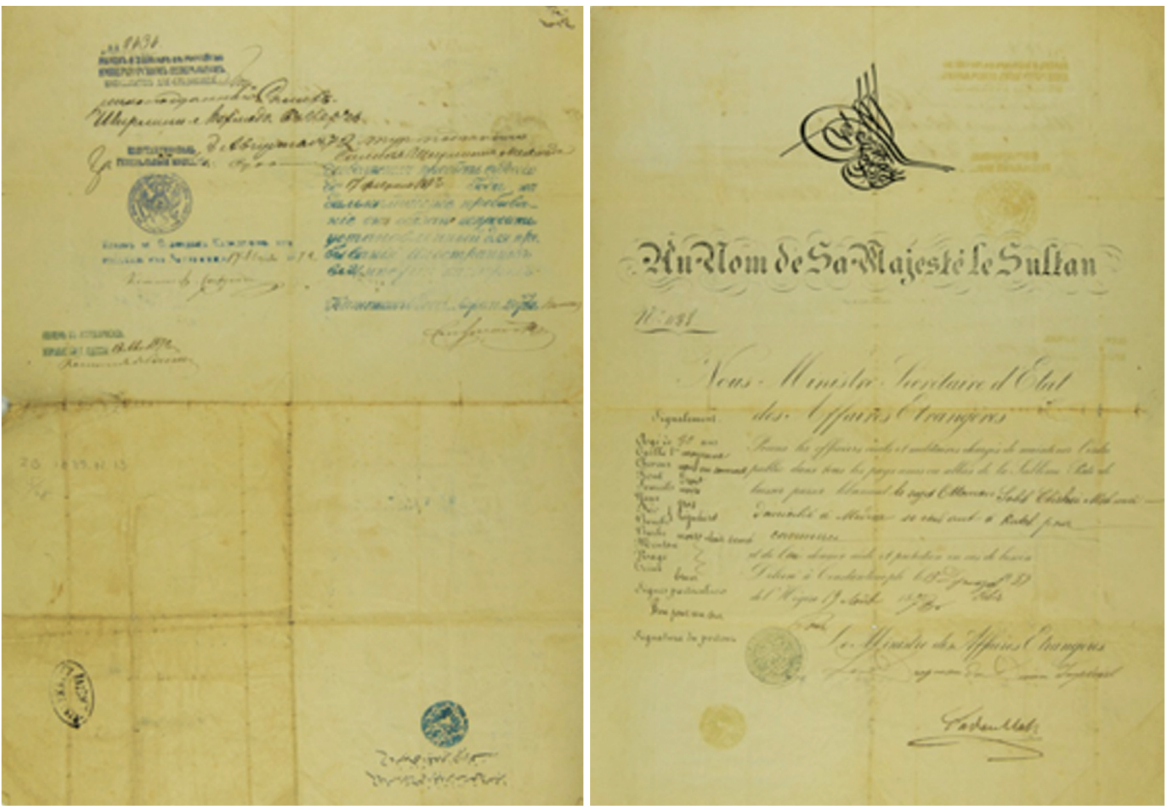

Source: (DOA. ZB. 5/48)

The owners of the trip permissions would show the documents to the local administrators or officers upon their arrival, and the authorities would stamp, signed and dated the back of the documents while they were leaving the settlement. In those regions where epidemics were occuring, the back of the travellers' documents were written that they didn't have any diseases while leaving the state. ${ }^{20}$

The "mürur" trip permission was redesigned along with the modern state organization structured by II. Mahmud period. Passport regulations inside the country were institutionalized thanks to "Mürur Nizamnameleri" in this period in which there weren't official passport regulations in practice. The Rum Riots in 1820 s and the abolition of Janissary corps of the Ottoman Empire in 1826 affected the mürur practices and its supervision. Following the Rum Riots, there were some claims that several spies existed among the Rums in İstanbul, so the Rums who lived in the settlements of İstanbul were made to pay bail after their numbers were determined. It was especially declared that those without the trip permission couldn't enter İstanbul, and even couldn't go to Anatolia. In addition to the Rum Riots, an emergency state was declared due to the start of Janissary corps' riot, and a great number of Janissary were killed or exiled. On the other hand, it was thought that those exiled out of the state might try to

${ }^{20}$ Mübahat Kütükoğlu, 2006.

\section{History Studies}


come back as they were accustomed to earning their life in İstanbul, and so 'Mürur Nizamı' practices were put into effect. ${ }^{21}$

It was attempted to ensure a sustainable peace and to control the social movements through "Men-i Mürur Nizzamnamesi", which was put into practice in 1841. The fifth article of this document was related to travels to abroad. In this article, it was stated that those who wished to go to a place out of the Ottoman Empire had to find a guarantor to take an official permission. Following this, they had to apply to the ambassy of the country they would like to visit and ask for to sign the official permission. When the individual preferred to do these steps out of İstanbul, they could take the official permission from the local council and complete the process through consulates of the country they would visit. ${ }^{22}$

'Men-i Mürur Nizamnamesi', issued in 1841, didn't include any clear articles on the entrance and exit of the tourists, so a new nizamname called as 'Memalik-i Mahruse-i Şahane Mürur and Ubur' in 1844 was declared. According to this new document, it was mentioned that travellers had to own a passport regardless of the route, either from abroad to the Ottoman territories or vice versa. Those from the nationalities that the Ottoman Empire had diplomatic relations had to submit their passports to the consulated to be issued. The tourists who entered the country from the highway had to show their passports to the passport officers in the border, whereas those preferring the seaway were controlled by port officers. ${ }^{31}$

Those using ferries or sailing ships, on the other hand, needed to submit their passports to the captains in order to get a permission form (pusula) in return for it. After the captains delivered the passports to the officers, those who came to İstanbul would get their passports back in 24 hours, while those outside İstanbul would submit the permission form and take their passports. If they intended to stay, they had to predicate where and how long they will stay. When the visitors couldn't submit their passports or give a reasonable excuse, they would be deported from the Ottoman territories. In the event of determining a fake passport or travel document, those would be deported, following the contacting with the diplomatic representatives of the other countries. Those who showed their passports wished to stay in the Ottoman Territories needed to get a residence permit from the diplomatic representatives and made it stamped by local authorities. Likewise, foreigners had to apply through the document given by the representatives so that they could obtain the trip permission. All male tourists over 15 had to complete these steps ${ }^{31}$.

The Ottoman Empire issued a new trip permission (Mürur Nizannamesi) in 1887 to keep up wih the changes occuring across the world and satisfy the reform demands of the Westerners following the Berlin Treaty, signed in 1878. Advances in communication and transportation, increased national and international travelling opportunities, and the prevalence of trade among the countries, even the continents forced the Ottoman Empire to take strict precautions to keep the peace in its territories. On the other hand, it was an obligation to get the nationalist and discriminatory movements under control. To achieve this, it was necessary to write the information on the country, hometown, address, occupation, age, pyhsical appearance, name of the father, reputation and birth place on the trip permission. Additionally, individuals had to show their trip permissions to the police if asked to do so. ${ }^{23}$

${ }^{21}$ Nalan Turna, Osmanlı İstanbulu'nda İç Pasaport: Mürûr Tezkeresi. Osmanlı İstanbulu II, Ed: Feridun M. EmecenAli Akyıldız- Emrah Safa Gürkan, İstanbul, 2014, p.389-392.

${ }^{22}$ Nalan Turna, 19. yüzyıldan 20. yüzyıla Osmanlı topraklarında: seyahat, göç ve asayiş belgeleri: Mürûr tezkereleri. İstanbul: Kaknüs Yayınları, 2013.

${ }^{23}$ Düstur, Birinci Tertib, Ankara 1937, p.861-865. 
The trip permission practice was abolished in July 1910 even though there were concerns about the fact that this would lead to security problems or impact the spread of the epidemics. However, another document called as "seyahat varakası (hereafter, travel certificate)" was issued as a security precaution with the start of the First World War. It is a significant issue that what the travellers thought about the trip permission practice during the Ottoman Period. For example, J. Rendel Harris rebuked that he was able to take the trip permission at the last minute and was about the miss the ferry, but he didn't conceal his satisfaction on the service during the journey ${ }^{31}$.

\section{Passport Regulations}

The incredible expansion of tourism activities in the second part of the $20^{\text {th }}$ century has some effect on the passport and border control practices and regulations. ${ }^{24}$ Before focusing on these changes and innovations, it wouln't be refresh our understanding about what passport is and its functions in the light of the related literature. A passport is a kind of official document that is the evidence of the permission from a country to its citizens so that they can travel to foreing countries and come back to their motherlands. It is also defined as a request to foreign countries so they they allow its citizens to pass freely and safely ${ }^{25},{ }^{26}$. O'Byrne $(2001)^{33}$ argues that the passport is the most significant symbol of the nationstate system. The author notes that the flag certainly represents the cultural importance and independence, but the passport conveys a deeper, political message of the nationstate system ${ }^{33}$. In this sense, it can be concluded that the passport can be considered as a political tool as it enables an administrative body to discriminate who can or cannot travel in its name. In this sense, the passport holds important functions. For example, the information about the native languages of the individuals were also written in the passports. Furthermore, the Dutch and the British passports were including items requesting their citizens to allow them to pass freely without any restriction ${ }^{33}$. Valocci (1992), ${ }^{27}$ on the other hand, notes that the Swedish passport includes no statement linked to the nationstate of the individual, thereby emphasizing the welcome of the foreigners and encouraging them to attend language classes to learn their language.

O'Byrne $(2001)^{33}$ mentions that if the tourist is the consumer, then does the passport function as the currency required to purchase the product? In this statement, the passport can be considered as a symbolic currency. Said another way, the passport is the onset of the other adventures during a visit to a foreign country. The advances in the means of transportation have also had an effect on passport regulations ${ }^{28}$. However, The origin of the passport practice dates back to the $11^{\text {th }}$ century, ${ }^{29}$ in which Spanish officials issued the first guidaticum (from an Arabic word meaning friendship). Following this, "passport letters" were circulated during wartime. By the mids of the $19^{\text {th }}$ century, European countries, especially France started to issue travel documents for the citizen at any time. In this sense, Turkey, along with Italy, were among the countries that asked for a visa rather than a passport for the entrance in their

\footnotetext{
${ }^{24}$ Darren O'Byrne, 2001.

${ }^{25}$ Rona Aybay, Passports of the past, 2013, http://earsiv.sehir.edu.tr:8080/xmlui/bitstream/handle/11498/24960/001584519010.pdf?sequence=1.(D.A:03.06.201 9)

${ }^{26}$ Henry Campbell Black, Black's Law Dictionary with Pronunciation (Centennial Edition 1891-1991), 1990.

${ }^{27}$ Steve Valocchi, The origins of the Swedish welfare state: a class analysis of the state and welfare politics. Social Problems, 39(2), 1992, p. 189-200.

${ }^{28}$ James Ryan, "Unveiling" the Tramway: The Intimate Public Sphere in Late Ottoman and Republican Istanbul. Journal of Urban History, 44(5), 2018, p. 811-834.

${ }_{29}$ Robert Ignatius, The Guidaticum Safe-Conduct in Medieval Arago-Catalonia: a Mini-Institution for Muslims, Christians and Jews. Medieval Encounters, 1(1), 1995, p.51-113.
} 
territories. ${ }^{30}$ On the other hand, In the United States, the right to a passport has been regared as a constitutional right, following Kent $v$ Dulles 357 US $116(1958)^{31}$

The letter given by Artaserhas, the King of Persia to Nehemya, in antiquity in order that Nehemya could safely travel has been considered as the first passport over the course of history. ${ }^{32}$ Passport regulations have been subjected to more strict and global rules in today's world that is surrounded by advanced transportation as well as increased consciousness due to economical perspectives of museology and tourism. Especially, the security concerns of European countries following the French revolution and the desire to control the entrance and exit in their countries entailed them to put modern passport regulations into practice. ${ }^{33}$ On the other hand, the passports in France were commonly used to supervise the travellings inside and outside the country. ${ }^{34}$

Following the declaration of the Second Constitutional Era, aiming to promote freedom, there were some interesting developments about the passport regulations. During this period, it was suggested that any individual could travel without any restrictions and an official document. There were hot debates between those supporting the passport practice and the ones who are against the passport in the Meclis-i Mebusan Assembly. Finally, it was concluded that a passport is a kind of document that enables an individual to travel foreign countries, but it shouldn't be an obligation to travel other countries. However, this legislation, issued in 1911, was abolished and the citizens had to take passport in line with the legislation called "Pasaport Kanunu Muvakkati". Said another way, the obligatiory passport legislation was brought back through this legislation. "Pasaport Kanunu Muvakkati". was rewritten in 1915, being added some new words, but this legislation, on the other hand, was abolished in $1938 .^{43}$ Therefore, it can be considered as the last legislation on passport during the Ottoman Empire period.

Figure 2: The Ottoman Empire in 1600

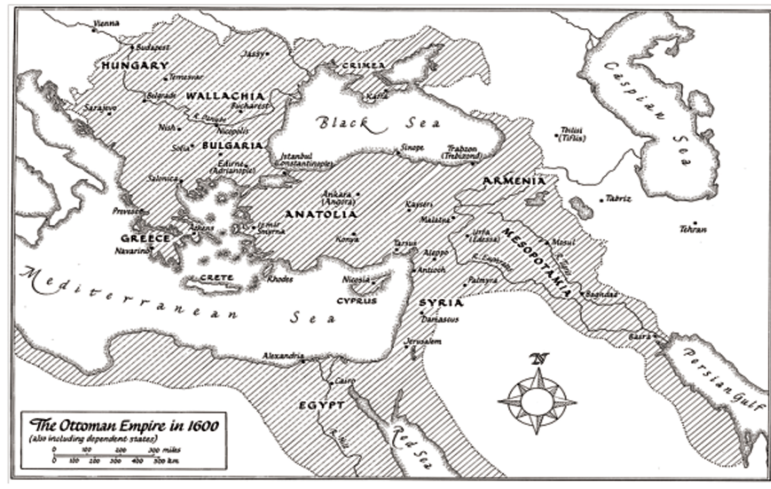

Source: (Dankoff \& Kim, 2011). ${ }^{35}$

${ }^{30}$ Garry Davis and Greg Guma, Passport to freedom: A guide for world citizens. Seven Locks Press, 1992.

${ }^{31}$ A. Nicol, Nationality and Immigration. In Rights of Citizenship, R. Blackburn, ed.,London: Mansell,1993, p.254270.

${ }^{32}$ Tuba Soysal, Sınırdışı (Deportation) ve Suçluların İadesi (Extradition) İlişkisi: Bağlantılar, Farklar ve Değerlendirme. Adalet Dergisi, 59, 2017, p. 7-31.

${ }^{33}$ İlkay Yılmaz, Serseri, Anarşist ve Fesadın Peşinde: II. Abdülhamid Dönemi Güvenlik Politikaları Ekseninde Mürur Tezkereleri, Pasaportlar ve Otel Kayıtları. İstanbul: Tarih Vakfi Yurt Yayınları,2014.

${ }^{34}$ Rona Aybay, Passports of the past, 2013.

http://earsiv.sehir.edu.tr:8080/xmlui/bitstream/handle/11498/24960/001584519010.pdf?sequence=1.(D.A:03.06.201 9)

${ }^{35}$ Robert Dankoff and Sooyong Kim, An Ottoman Traveller: Selections from the Book of Travels of Evliya Çelebi. London: Eland, 2011.

\section{History Studies}

HISTORY STUDIES

2010

Volume 11

Issue 6

December 2019 
During the modern ages, in which sealed letters of Kings in Europe were used as passports, such documents as 'il-can mektubu' or 'il-can name' was employed to ensure the survival and protecting the belongings of the owners of these documents. Towards the $19^{\text {th }}$ century, the names of these documents were changed as passports due to modernization movements in the Ottoman Empire. ${ }^{36}$ Even though modern passports were being used in the reform age in Europe, there were no legislative regulations on passports in the Ottoman period despite calling these documents as passports. As a matter of fact, many Ottoman citizens attempted to obtain the passports of different countries to avoid the punishments or taxes during the reign of III. Selim. The Ottoman Empire wasn't fully successful with in the efforts to prevent this despite some regulations. ${ }^{37}$

During the height of their reigns, the Ottoman Sultans ruled over a vast intercontinental empire, so it was a necessity to record every piece of information related to the matters of the state. ${ }^{38}$ In this sense, the first legislation on passports during the Ottoman period was "Pasaport Odas1 Nizamnamesi", issued in 1867 that were practiced for 17 years until 1884, when a new "Passport Nizamnamesi" was enacted. This new legislation necessitated the Ottoman citizens to take passport when they wished to go abroad. Furthermore, there were detailed regulations in issuing a passport to a citizen. Correspondingly, those who wished to apply for a passport had to show "ilmühaber" document along with the official document including information about their personal background. Officer citizens could take "ilmübaher from their seniors, muslim citizens from their prayer leaders or mukhtars, non-muslims from partiarchates, rabbinates, or metropolitans. The passports were prepared in Turkish and French languages and issued for one year at most. Additionally, if the travellers visited foreign countries together with their families or servants, the information about them were also written on their passports as well as their personal demographic information. This legislation also included items allowing to give passports to poor people without charging any money. ${ }^{39}$ The United States' passport includes in its pages a different emblem of "the nation". Each page is decorated with individual state emblems. The message here would appear to be recognition of a "dual citizenship": American society, politics, and law operate at both state and federal levels. ${ }^{40}$

The first serious regulation for modern passport practice in the Ottoman territories was 'Memalik-i Mahruse-i Şahane Mürur ve Ubur' issued in 1844. Although foreigners were obliged to own some official documents to visit the Ottoman territories, the first passport law 'Passport Room Regulation (Pasaport Odası Nizamnamesi)' was issued on $14^{\text {th }}$ February 1867. In accordance with this regulation, the passport was an obligation for entrance and exit in the Ottoman territories. Based on the legislation, those who wanted to visit the Ottoman territories were required to submit their visas in their passports to the officers at the gate in the border, whereas individuals who preferred the seaway were obliged to show their visas to the officers at the ports. Tourists had to declare how they would spend inside the country and where they would accommodate in 24 hours time from the entrance to the country and take the official

\footnotetext{
${ }^{36}$ Şinasi Tekin, Türkiye'de XV. Yüzyıla Ait İki Pasaport İl-can Mektubu ve İl-can Name. Tarih ve Toplum, 1985, p. $9-11$.

${ }^{37}$ İbrahim Serbestoğlu, Osmanlı kimdir? Osmanlı Devleti'nde tabiiyet sorunu. İstanbul: Yeditepe Yayınevi.,2014.

${ }^{38} \mathrm{Naim}$ Farooqi, An Overview of Ottoman Archival Documents and Their Relevance for Medieval Indian History. The Medieval History Journal, 20(1),2017, p. 192-229.

${ }^{39}$ Rona Aybay, Passports of the past, 2013.

http://earsiv.sehir.edu.tr:8080/xmlui/bitstream/handle/11498/24960/001584519010.pdf?sequence=1.(D.A:03.06.201 9)

${ }^{40}$ Darren O'Byrne, 2001.
}

\section{History Studies}


permission. "Passport Odas1 Nizamnamesi" was the oldest regulation, issued in 1867 in the Ottoman Norms. This legislation didn't contain any items about the exit of the Ottoman citizens but includes some regulations on those who wished to visit the Ottoman territories. Figure 3 displays a sample of passport issued for a Serbian named as Jivko Tsukiç.

Figure 3: The passport of a Serbian, named as Jivko Tsukiç

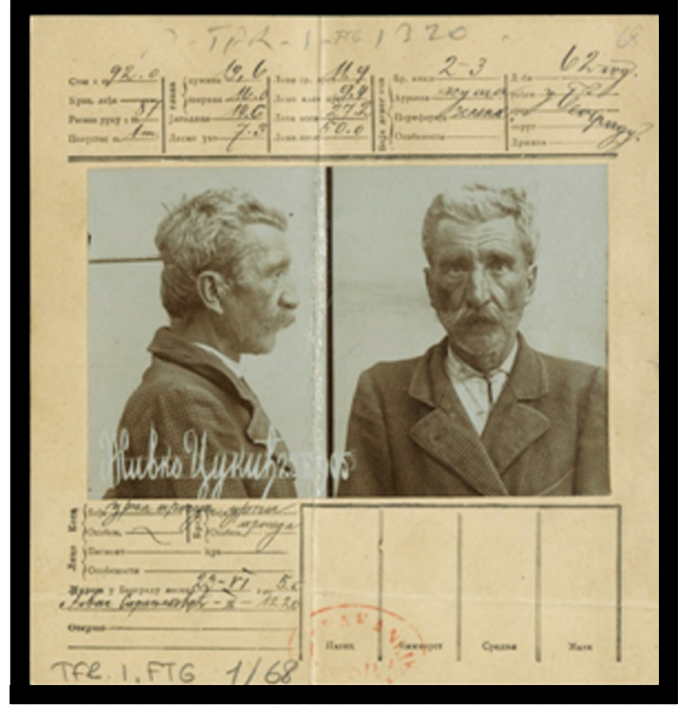

TFR.I.FTG.00001.00068.001

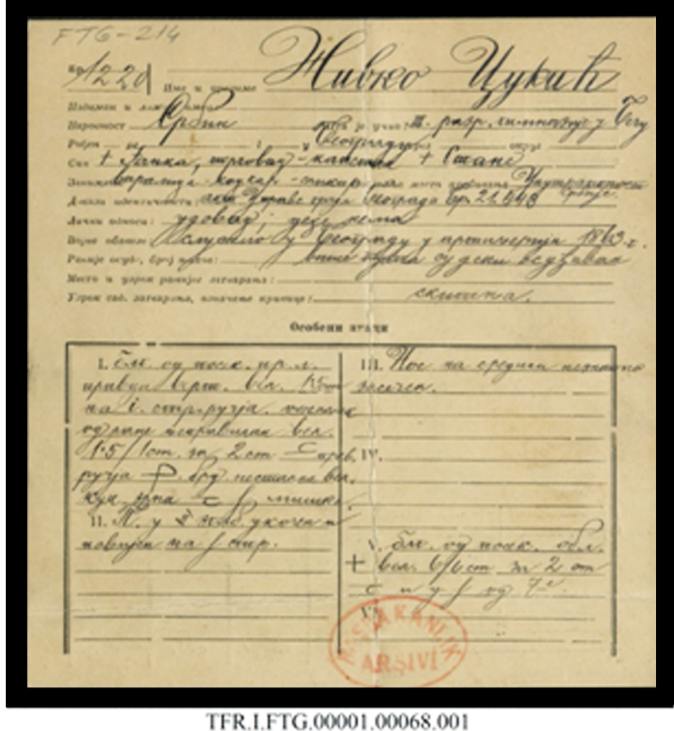

TFR.I.FTG.00001.00068.001

Source: (DOA. TFR.I.FTG. 1/68)

During the practice of passport legislation, there occured some problems, but they were compensated in the nick of time, and the practice continuted. Since the tourists arrived in the country as huge crowds, they demanded that they would be free to pay visa fee, but the state didn't made concessions. For example, a tourist group of 300 people from Romanian who wanted to visit İstanbul to watch the fest held for the declaration of II. Constitutional on the tenth of July demanded to enter the country and "the tourists need to obey legislative process" replied the Ottoman authorities ${ }^{42}$. On the other hand, there were some circumstances that the Vezir-i Azam, and even the Sultan, himself, issued some documents to make the travels of the foreigners easier in the Ottoman territories. For example, based on the statements of Bishop Gerlach, who was appointed as an ambassador in Austria Embassy, the foreigners were able to get passports in the Ottoman territories. Similarly, the private doctor of the Austia Ambassador stated that he was issued a passport (Freiheits-Brief) by the Sultans.

\section{Discussion and Conclusion}

This paper has sought to shed light on the official practices of the legislations on the entrance to the Ottoman Empire territories, travelling inside the country, and passports. A systematic review of literature has revealed that the studies on the historical development of tourism mostly focus on the period after the declaration of Turkish Republic. It can be noted that very few scholars have examined the legal regulations related to tourism during the

\footnotetext{
41 Musa Çadırcı, Tanzimat döneminde çıkarılan men'-i mürür ve pasaport nizamnameleri. TTK Belgeler, XV/19,1993, p. 178-181.

42 DOA, DH. EUM. THR, 105/4 (The Directorate of Republican Archives and the Directorate of Documentation, The Directorate of Ottoman Archives).
}

\section{History Studies}

\section{HISTORY STUDIES \\ 2012 \\ Volume 11 Issue 6 December 2019}


Ottoman Period. Additionally, there is evidence to suggest that existing literature mostly includes the studies conducted by scholars from department of historical studies, and they approached the issue through their own discipline. However, this study has focused on the issue from the tourism perspective.

It has been widely acknowledged that tourism has a significant role in getting people and countries closer, thereby contributing the mutual understanding. It is also an important source of income and employment ${ }^{43}$. At this precise point, it should be noted that the right to travel is the basis of all other rights, as they rest on freedom of movement. ${ }^{44}$ From this perspective, when we examined the legislative regulations on the tourism during the Ottoman Period, it is seen that there are similarities between the old practices and the current ones in terms of tourism law. Said another way, it can be noted that the foundations of most of the current practices related to tourism directly or indirectly were laid down during the Ottoman Period.

All the evidence pointed to the conclusion that this study contributes to the literature through its findings on tourism regulations about the entrance and exit of the Ottoman territories, and the passport regulations.A review of literature has revealed that there is no study focusing these issues in a study by a scholar from the department of tourism. This paper is to contribute to the current literature about the tourism during the Ottoman Empire period, by putting forward that the state didn't actually enact these practices not just for tourism, but for the safety of its territories, as well. This means that the current officials in the tourism sector can learn more about the practices and make inferences for the current practices, too. In a nutshell, the Ottoman Empire was a huge state that paid attention to the legislative issues linked to the foreign visitors from their entrance to the country to their travels inside its territories.

\section{Highlights}

- The tourism regulations during the Ottoman Empire period concur well with the current ones.

- The Ottoman Empire paid utmost attention to the travel freedom of the foreigners as well as its own citizens.

- There were effective means of recording system of the entrance and exit the state during the Ottoman Empire.

- The Ottoman Sultans had the awareness of the foreigner who visited their countries no matter what purposes they had.

\section{Limitations and recommendations for further research}

This research has several limitations, most notably that the findings based on the data collected via the document analysis. The findings of this paper rest on the data that were obtained from the documents in the archives. However, given the longevity and vast territories of the Ottoman Empire, it wouldn't be wrong to say that the documents obtained in this study are grains of sand in the magnificient reign of the Ottomans. Another limitation is that this paper has just focused on the official documents in the archives. It would be more fruitful to examine the travelogues and memories of the visitors of the Ottoman territories. On the basis of the promising findings presented in this paper, further research on the more specific tourism activities during the Ottoman Empire would be interesting and beneficial. Additionally, new studies can focus on the tourist attractions that still survive today and make some inferences about the tourism regulations of the Ottoman Empire.

\footnotetext{
${ }^{43}$ Korel Göymen, Tourism and governance in Turkey. Annals of Tourism Research, 27(4), 2000, p. 1025-1048.

${ }^{44}$ Darren O'Byrne, 2001.
} 


\section{References}

AYBAY, Rona, Passports of the past. http:/earsiv.sehir.edu.tr:8080/xmlui/bitstream/handle/11498/24960/001584519010.pdf?se quence=1. (D.A:03.06.2019),1993.

BLACK, Henry Campbell, Black's Law Dictionary with Pronunciation (Centennial Edition 1891-1991), 1990.

ÇADIRCI, Musa, Tanzimat döneminde çıkarılan men'-i mürür ve pasaport nizamnameleri. TTK Belgeler, XV/19, p.178-181,1993.

DANKOFF, Robert- Sooyong Kim, An Ottoman Traveller: Selections from the Book of Travels of Evliya Çelebi. London 2011.

DAVIS, Garry- Greg Guma, Passport to freedom: A guide for world citizens. Seven Locks Press., 1992.

DOA, DH. EUM. THR, 105/4 (The Directorate of Republican Archives and the Directorate of Documentation, The Directorate of Ottoman Archives).

DOA. TFR.I.FTG. 1/68 (The Directorate of Republican Archives and the Directorate of Documentation, The Directorate of Ottoman Archives).

BOA. ZB. 5/48 (The Directorate of Republican Archives and the Directorate of Documentation, The Directorate of Ottoman Archives).

DUSTUR, Birinci Tertib, Ankara 1937, s. 861-865

FAROOQI, Naim, "An Overview of Ottoman Archival Documents and Their Relevance for Medieval Indian History", The Medieval History Journal, 20(1),2017,p. 192-229.

GÖYMEN, Korel, "Tourism and governance in Turkey" Annals of Tourism Research, 27(4),2000, p. 1025-1048.

HOGANSON, Kiristin, "Cosmopolitan domesticity: Importing the American dream, 18651920", The American Historical Review, 107(1),2002, p. 55-83.

İLHAN, Mehdi, "An Overview of the Ottoman Archival Documents and Chronicles", Tarih Araştırmaları Dergisi, 27(44), 2008, p. 21-40.

JUPP, Victor, The Sage dictionary of social research methods, London 2006.

KUŞ, Ayşegül, "Henry John Van Lennep"e Göre Amasya", GOSOS/Gaziosmanpaşa Üniversitesi Sosyal Bilimler Araştırmaları Dergisi, 11/1,2016

KÜTÜKOĞLU, Mübahat, Mürur Tezkiresi. TDVIA, c. XXXII, Ankara,2006.

LOWRY, Heath, "Ottoman Bursa in travel accounts", Tarih Incelemeleri Dergisi, 20(1), 2013, p.211-212.

MACLEAN, Gerald, Writing Turkey: Explorations in Turkish history, politics, and cultural identity. London: Middlesex University Press 2006.

\section{History Studies}


MENGÜ, Cüneyt, Sezgi Gedik, Suna Muğan Ertuğral, "The Central Government Efoorts to Promote Tourism in The Ottoman Empire", Osmanlı Mirası Araştırmaları Dergisi,6/14, 2019, s. 115-127.

NANCE, Susan, "A facilitated access model and Ottoman Empire tourism", Annals of Tourism Research, 34(4),2007,p. 1056-1077.

NESTOROSKA, Ivan- Biljan Petrevska - Peter Namicev, Ottoman heritage tourism flows in Macedonia. Yearbook-Faculty of Tourism and Business Logistics, 3(2), 2018, p. 89-99.

NICOL, A. "Nationality and Immigration", Rights of Citizenship, R. Blackburn, ed., London 1993, pp. 254-270.

DARREN, O'Byrne, “On passports and border controls”, Annals of Tourism Research, 28(2),2001, p. 399-416.

RYAN, James, "Unveiling the Tramway: The Intimate Public Sphere in Late Ottoman and Republican Istanbul", Journal of Urban History, 44(5), 2018,p. 811-834.

SERBESTOĞLU, İbrahim, Osmanlı kimdir? Osmanlı Devleti'nde Tabiiyet Sorunu, İstanbul 2014.

SHOVAL, Noam, Kobi Cohen-Hattab, "Urban hotel development patterns in the face of political shifts", Annals of Tourism Research, 28(4), 2001, p.908-925.

SOYSAL, Tuba, "Sınırdışı (Deportation) ve Suçluların İadesi (Extradition) İlişkisi: Bağlantılar, Farklar ve Değerlendirme", Adalet Dergisi, 59,2017,p. 7-31.

TEKİN, Şinasi, “Türkiye'de XV. Yüzyıla Ait İki Pasaport İl-can Mektubu ve İl-can Name”, Tarih ve Toplum, 1985, p. 9-11.

TOPRAK, Zafer., "Seyyah'tan 'Turist'e 'Sinâat'tan 'Endüstri'ye "Ecânib Sinâatı" (Türkiye'e 'Ecânib Sınâatı' ya da 'Turizm Endüstrisi”, İstanbul: Tarih Vakfi Yayını, 6,1993, P.6669.

TURNA, Nalan, 19. yüzyıldan 20. yüzyıla Osmanl topraklarında: seyahat, göç ve asayiş belgeleri: Mürûr tezkereleri, Kaknüs Yayınları, İstanbul 2013.

TURNA, Nalan, “Osmanlı İstanbulu'nda İç Pasaport: Mürûr Tezkeresi”. Osmanlı İstanbulu II, Ed: Feridun M. Emecen- Ali Akyıldız- Emrah Safa Gürkan, İstanbul 2014, p. 389-392.

VALOCCHI, Steve, "The origins of the Swedish welfare state: a class analysis of the state and welfare politics", Social Problems, 39(2),1992, p. 189-200.

WALLIMAN, Nicholas, Social research methods: The essentials, Sage, London 2015.

YILDIRIM, Ali- Hasan Şimşek, Sosyal Bilimlerde Nitel Araştırma Yöntemleri, Seçkin Yayınc1lık,Ankara 2008.

YILMAZ, İlkay, Serseri, Anarşist ve Fesadın Peşinde: II. Abdülhamid Dönemi Güvenlik Politikaları Ekseninde Mürur Tezkereleri, Pasaportlar ve Otel Kayltları. Tarih Vakfı Yurt Yayınları, İstanbul 2014. 